\title{
THE EFFECTIVENESS OF USING THE MATHEMATICS LEARNING COMPACT DISK RELATED TO SET MATERIAL ON THE LEARNING OUTCOMES IN MTS AL-FURQON SANDEN
}

\author{
Eko Budi Isnanto ${ }^{\text {a }}$, Suparman ${ }^{\mathrm{b}}$ \\ Program Studi Pendidikan Matematika Universitas Ahmad Dahlan \\ Jalan Ring Road Selatan, Tamanan, Banguntapan, Bantul Yogyakarta \\ a $\underline{\text { ekobudiisnanto@gmail.com, }}$, suparmancict@ pmat.uad.ac.id
}

\begin{abstract}
Learning mathematics is still dominated by the teachers and some students still assume that mathematics is a hard subject. The lack of variation in the implementation of learning mathematics can influence the results of students' mathematics learning. Fortunately, there is one way to improve the students learning outcomes which is by using Mathematics Learning CD (compact disk). The purpose of this study is to determine the learning outcomes between the students who use Mathematics learning CD with those who do not use CD. The study is done in MTs Al Furqon Sanden District Bantul. The population of this study was the seventh-grade students of MTs Al Furqon Sanden in School Year of 2015/2016, which comprises of 3 classes with a total of 64 students. The experiment class was VIIA and class VII Bas the control class that was selected by random sampling of classes. The methods of data collection using documentation and test. The research instrument is in the form of questions. The test instrument is used for validity, reliability and distinguishing features. Prerequisite test data analysis is used for Normality Test, Homogeneity Test, and Hypothesis Testing. Hypothesis test results with a significance level of 5\% and 42 degrees of freedom showed that: (1) there are differences in learning outcomes of mathematics that using CD mathematics learning with the expository method. It can be seen in $t_{c a l}=7.2809$ and $t_{\text {table }}=2,0183$ so $t_{\text {cal }}>t_{\text {table }}$ and (2) Learning mathematics using CD is more effective than learning without using Mathematics CD. This is indicated by the $t_{\text {tabel }}=7.1989$ and $t_{\text {cal }}$ $=7.2809$, so $t_{\text {cal }}>t_{\text {table }}$.
\end{abstract}

Key Words: Effectivity, Learning CD, Mathematics Learning Outcomes.

\section{INTRODUCTION}

Education is an important thing in human life because through education humans can understand various sciences. This will continue to occur along with the development of unlimited and uninterrupted human needs. The importance of education is, of course, the concern and priority of the government concerned because with good education it will produce a superior generation that will be the generation of national leaders, and other professions that are certainly important for the Indonesian people. Mathematics is one branch of science that has an important role in human life. According to the Ministry of National Education (2008: 13) "Mathematics is a universal science that underlies the development of modern science and technology, has an important role in various disciplines and advances human thinking". The rapid development in the field of information and communication technology today is based on the development of mathematics in the field of number theory, algebra, analysis, opportunity theory, and discrete mathematics. To master and create technology in the future requires a strong mastery of mathematics from an early age. Therefore, Mathematics is a subject that has been taught to students since they studied in elementary school, even before entering formal education they have been introduced to mathematics in the form of simple numbers and counts used in everyday life. The paradigm that has developed to date in both the scope of society and students is that mathematics subjects are difficult, boring, and can be said to be scary subjects. Understanding learning mathematics according to Uno, Hamzah B. (2007: 130), "The essence of learning mathematics is mental activity to understand the meaning and relationships and symbols, then applied to real situations".

The results of interviews with students (students) conducted on June 23, 2015, showed that mathematics is one of the subjects feared by some seventh-grade students of MTs Al-Furqon Sanden. Based on observations, this was caused by teachers applying teaching methods with excessive emphasis on memorization only, emphasis on speed of counting, authoritarian teaching, lack of media use, and lack 
of variation in the use of learning models. Besides, there are still many students who encounter difficulties when solving math problems. The learning process carried out by the teacher is to use the expository method (without using learning media) varies by giving examples of questions, explaining, then students are given the task of working on the problem. In mathematics learning it is very rare for teachers to use educational media, even if using educational media is usually in the form of pictures, textbooks, replicas of money, examples of tubes, circles, cubes, and similar objects. The learning process carried out by the teacher in the class is very influential on the interests and student learning outcomes, as well as the learning media used. Understanding of mathematics learning outcomes according to Uno, Hamzah B. (2007: 139), namely: Student learning outcomes in mathematics subjects are the results of activities from learning mathematics in the form of knowledge as a result of treatment or learning carried out by students. Or in other words, student learning outcomes in mathematics are what students get from the learning process of mathematics.

The above can be indicated by the results of the UTS (Middle Semester Examination) mathematics of class VII students who are still low. The results of the observations also show that the mathematics scores of students have not yet reached the established KKM (minimum completion criteria). The KKM mathematics lesson in this school is 75 . The percentage of grade VII mastery learning in MTs Al-Furqon Sanden students is only 0\% VIIA class, 0\% VIIB class, and 10\% VIIC class. Most students still do not meet the KKM criteria, this is because mathematics learning in schools is still results-oriented, teacher-centered, assignment, lack of variation in learning, and lack of use of learning media in mathematics learning. The data is completely presented in table 1.

Table 1. Result of UTS Mathematics Grade VII Mts Al-Furqon Sanden Even in the Semester of 2015/2016 Academic Year.

\begin{tabular}{|c|c|c|c|c|c|}
\hline \multirow{2}{*}{ Class } & \multicolumn{2}{|c|}{$\geq$ KKM 75 } & \multicolumn{2}{c|}{$<$ KKM 75 } & \multirow{2}{*}{$\begin{array}{c}\text { Number of } \\
\text { students }\end{array}$} \\
\cline { 2 - 5 } & Total & Percentage & Total & Percentage & 19 \\
\hline VIIA & 0 & $0 \%$ & 19 & $100 \%$ & 25 \\
\hline VIIB & 0 & $0 \%$ & 25 & $100 \%$ & 20 \\
\hline VIIC & 2 & $10 \%$ & 18 & $90 \%$ & \\
\hline
\end{tabular}

(Source: MTs Al-Furqon Sanden)

Besides, based on an interview with the math teacher MTs Al-Furqon Sanden on Tuesday, June 23, 2015, in mathematics learning the teacher still uses the expository method (without using learning media). This causes teachers to be more dominant in the mathematics learning process as a result of which student learning outcomes in mathematics are still low. So that the value of many students who have not reached the KKM value. So that students are less interested in learning mathematics.

Based on the above, the researcher wants to research learning media used in mathematics learning, namely media CD (Compact Disk) learning mathematics and its influence on student learning outcomes. Understanding learning CD is one of the learning media that can be spelled out new. This media is the development of internet technology which has been growing rapidly lately. Daryanto (2013: 41) states that the learning $C D$ (compact disc) is a file storage media created to streamline its storage system. Besides being slim, CDs can store more files when compared to cassettes. With the CD the sound quality produced is better. The tools needed to play CDs are CD Player, VCD Player, DVD Player, or via $\mathrm{CD}$ room on a computer. In other words, the learning $\mathrm{CD}$ is a $\mathrm{CD}$ that contains menus that can display certain information. The advantage of the learning $\mathrm{CD}$ is that it can help sharpen the message conveyed because it is a combination of view, sound, and movement. The Learning CD used is the Learning CD about the set created by Aditya Risky Prapasa. The research takes the issue of the effectiveness of using CD (Compact Disk) learning mathematics on student learning outcomes about the set in class VII students of MTs Al-Furqon Sanden, Bantul Regency. 
Based on the description above, the formulation of the problem in this study are:

1. Are there differences in mathematics learning outcomes of students who use mathematics learning CDs with students without using mathematics learning CDs for VII grade students of Al-Furqon Sanden MTs in Bantul Regency?

2. Which is more effective between the mathematics learning outcomes of students who use mathematics learning CDs with students without using the mathematics learning CD in class VII students of Al-Furqon Sanden MTs in Bantul Regency?

While Based on the formulation of the problem, the objectives in this study are:

1. To find out whether or not there are differences in mathematics learning outcomes of students who use mathematics learning CDs with students without using mathematics learning CDs for class VII students of MTs Al-Furqon Sanden, Bantul Regency.

2. To find out which is more effective between the mathematics learning outcomes of students who use mathematics learning CDs with students without using mathematics learning CDs for class VII students of MTs Al-Furqon Sanden, Bantul Regency.

\section{METHODS}

This study involved two classes namely the experimental class and the control class. Both classes have the same ability and the same material, but the treatment is different in the material delivery process. The process of delivering experimental class material using mathematics learning $\mathrm{CD}$, by the way, the teacher plays the mathematics learning $\mathrm{CD}$ and the students observe it. While the process of delivering material to the control class without using mathematics learning CD. In this study using a posttest-only control design. According to Sugiyono, (2011: 112). In this design, there are two groups, each chosen randomly (R). The first group is treated (X) and the second group is not. The treated group is called the experimental group and the untreated group is called the control group. The effect of treatment is $\mathrm{O}_{1}$ : $\mathrm{O}_{2}$. In real research, the effect of treatment was analyzed by different tests, using t-test statistics for example. If there is a significant difference between the experimental group and the control group, then the treatment given has a significant effect. Research Design Using Posttest-Only Control Design can be seen in table 2 .

Table 2. Research Design Using Posttest-Only Control Design.

\begin{tabular}{|c|c|c|c|}
\hline Experimental Group & $\mathrm{R}$ & $\mathrm{X}_{1}$ & $\mathrm{O}_{1}$ \\
\hline Control group & $\mathrm{R}$ & $\mathrm{X}_{2}$ & $\mathrm{O}_{2}$ \\
\hline
\end{tabular}

Information:

R: Random

$\mathrm{X}_{1}$ : Experimental class that is treated using mathematics learning $\mathrm{CD}$

$\mathrm{X}_{2}$ : Control class is a class without using mathematics learning $\mathrm{CD}$

$\mathrm{O}_{1}$ : The posttest results of the experimental class

$\mathrm{O}_{2}$ : The posttest result of the control class

This research belongs to the type of experimental research. This research was conducted at MTs Al-Furqon Sanden even semester 2015/2016 academic year with class VII A as the experimental class, class VII B as the control class and class VII C as the Try class. The variables in this study were the use of mathematics learning CDs given to the experimental class, expository learning methods (without using mathematics learning CDs) in the control class, and mathematics learning outcomes of seventh-grade students in the MTs Al-Furqon Sanden in the school year of 2015/2016 Which was carried out on the 4th to the 13th of January 2016. The research was carried out in the experimental class and the control class with the set material, the teacher and the same number of meetings. After reaching the last sub-chapter, the two classes were given a test of learning outcomes which later the learning outcomes of the two classes would be seen to be the difference in the results so that more effective strategies were known. Data collection techniques in the form of documentation and tests. The instrument of data collection is in the form of initial ability tests and learning outcomes tests. Data analysis using normality, homogeneity, and t-test. 
The normality test is used to test whether the data obtained in each variable is normally distributed or not. If the data is normally distributed then data analysis can be done to prove the research hypothesis. In this case, the normality test uses the Chi-Square formula $X^{2}$.

$$
\chi^{2}=\sum_{i=1}^{k} \frac{\left(O_{i}-E_{i}\right)^{2}}{E_{i}}
$$

(Suparman, $2012: 6$ )

Information :

$X^{2}$ : Chi-square value

$O_{i}$ : Frequency of observation on interval class $-\mathrm{i}$

$E_{i}$ : Expected frequency on interval class - i

$k$ : The number of interval classes

$i: 1,2, \ldots \mathrm{k}$

A Homogeneity test is conducted to obtain the assumption that the research sample has the same or homogeneous conditions. The Homogeneity test is done by investigating whether the two samples have the same variance or not. Populations with equal variances are called populations with homogeneous variances. The formula used in the homogeneity test is the F statistical test:

$$
F=\frac{s_{1}^{2}}{s_{2}^{2}}
$$

(Sudjana, 2001:249)

With :

$$
s_{i}^{2}=\frac{n \sum x_{i}^{2}-\left(\sum x_{i}\right)^{2}}{n(n-1)}
$$

Information :

(Sudjana, 2001:94)

$F:$ Statistic test

$s_{i}^{2}$ : Sample variant to - i

Testing Criteria:

Accept it $\mathrm{H}_{0}$ if $\mathrm{F}_{(1-\alpha / 2)(n 1-1, \mathrm{n} 2-1)} \mathrm{F}<\mathrm{F}_{\alpha / 2(\mathrm{n} 1-1, \mathrm{n} 2-1)}$

The t-test formula is:

$$
t=\frac{\bar{X}_{1}-\bar{X}_{2}}{s_{p} \sqrt{\frac{1}{n_{1}}+\frac{1}{n_{2}}}}
$$

With :

$$
S_{p}^{2}=\frac{\left(n_{1}-1\right) S_{1}^{2}+\left(n_{2}-1\right) S_{2}^{2}}{\left(n_{1+} n_{2}\right)-2}
$$

(Suparman, 2011: 46)

Information :

t: Test statistics

$\bar{X}_{1}$ : The average value of students with mathematics learning CD (experimental class)

$\bar{X}_{2}$ : The average value of students with learning without using mathematics learning CD (control class)

$n_{1}$ : Number of students in the experimental class

$n_{2}$ : Number of control class students

$S_{1}^{2}$ : Variety of experimental class students

$S_{2}{ }^{2}$ : The variance in the control class

$S_{p}$ : Combined standard deviation

For two-party t-test if $t_{c a l}>t_{\frac{\alpha}{2}}\left(n_{1}+n_{2}-2\right)$, then $\mathrm{H}_{0}$ is rejected and $\mathrm{H}_{1}$ is accepted and for onepart t-test if $t_{c a l}>t_{\alpha}\left(n_{1}+n_{2}-2\right)$, then $\mathrm{H}_{0}$ is rejected and $\mathrm{H}_{1}$ is accepted. 


\section{RESULTS AND DISCUSSION}

Before being given treatment to the experimental class and the control class, the UTS score was used for the initial ability of the population. This is done to find out that the population of class VII MTs Al-Furqon Sanden has the same or homogeneous variance. The results of the test homogeneity of the initial ability of the eighth-grade students of MTs Al-Furqon Sanden. This homogeneity test was conducted to determine whether the value of the initial mathematical ability of the experimental class students and the control class was homogeneous or not.

Table 3. Homogeneity Test Results of the Early Ability of Class VII Students

\begin{tabular}{|c|c|c|c|c|c|c|}
\hline Class & $\boldsymbol{s}_{\boldsymbol{i}}^{\mathbf{2}}$ & \multirow{2}{*}{$\boldsymbol{F}_{\mathbf{0}}$} & $\boldsymbol{F}_{\text {table }}$ & \multirow{2}{*}{ Df } & \multirow{2}{*}{$\boldsymbol{a}$} & Information \\
\cline { 1 - 2 } & 154,4327 & \multirow{2}{*}{1,6818} & $\boldsymbol{F}_{\mathbf{0}, \mathbf{0 2 5}}$ & & \\
\hline Experiment & 15648 & $(18,24)$ & $5 \%$ & homogeneous \\
\hline Control & 91,8267 & &
\end{tabular}

Based on the homogeneity test that has been done in class VIIA and VIIB, it can be seen that $F_{0}=1,6818$ and $f_{0,025}(18,24)=2,3648$ because $F_{0}<f_{0,025}(18,24)$ which means that both classes have the same variance (homogeneous).

After it was known that the population of class VII students were homogeneous, then the instrument was tested which was tested in the trial class. Data analysis from this research instrument shows that from 20 questions, 2 questions are invalid. So that the number of questions used to test the mathematics learning outcomes of class VII students is 18 questions. While from the 18 items, it is known to have a very high-reliability level. The questions that are valid reliable and have good differential power are then given to the experimental class, namely the class that uses the learning $\mathrm{CD}$ and the control class, namely the class whose learning without using mathematics learning $\mathrm{CD}$. The results of the mathematics learning test can be seen in the following table 4 .

Table 4. Description of the Value of Mathematics Learning Outcomes

\begin{tabular}{|c|c|c|c|c|c|}
\hline \multirow{2}{*}{ Class } & \multicolumn{5}{|c|}{ Parameter } \\
\cline { 2 - 6 } & Value Max & Value Min & $\overline{\boldsymbol{X}}$ & $\boldsymbol{S}$ & $\boldsymbol{S}^{\mathbf{2}}$ \\
\hline Experiment & 89 & 78 & 83,6316 & 4,6811 & 21,9123 \\
\hline Control & 83 & 56 & 67,72 & 8,5903 & 73,7933 \\
\hline
\end{tabular}

Table 3 shows the minimum value, maximum value, and the average value of the experimental and control classes. It can be seen that the average value of the experimental class is higher than the mean value of the control class.

Then the two-party hypothesis was tested to determine whether there were differences in mathematics learning outcomes between the experimental class and the control class. Test criteria for two-party t-test: If $t_{c a l}>t_{\frac{\alpha}{2}}\left(n_{1}+n_{2}-2\right)$, then $\mathrm{H}_{0}$ is rejected and $\mathrm{H}_{1}$ is accepted at a significant level of $5 \%$. The results of the two-party hypothesis test can be seen in Table 5 below.

Table 5. Summary of the Two-Party Hypothesis Test for Mathematics Learning Outcomes

\begin{tabular}{|c|c|c|c|c|l|}
\hline$S_{i}^{2}$ & $S_{2}^{2}$ & Df & $t_{\text {cal }}$ & $t_{\text {table }}$ & Information \\
\hline 21,9123 & 73,7933 & 42 & 7,2809 & 2,0183 & $H_{0}$ rejected \\
\hline
\end{tabular}

Based on the results of the analysis carried out with a significant level of 5\% and 42 degrees of freedom, the values obtained $t_{c a l}=7,2809$ and $t_{\text {table }}=2,0183$, so $t_{c a l}>t_{\text {table }}$ So rejecting $\mathrm{H}_{0}$ and $\mathrm{H}_{1}$ is accepted which means that there are differences in mathematics learning outcomes using mathematics learning CDs with learning without using mathematics learning CDs for seventh-grade students of the MTs Al-Furqon Sanden in the 2015/2016 academic year.

From the two-party hypothesis test, it is known that there are differences in mathematics learning outcomes between the experimental class and the control class. Furthermore, one-party hypothesis testing is done to find out whether learning using a mathematics learning $\mathrm{CD}$ is more effective than learning without using a learning CD. One-party test criteria, if $t_{c a l}>t_{\text {table }}$, then $\mathrm{H}_{0}$ is rejected and $\mathrm{H}_{1}$ is accepted. 
With degrees of freedom df $=\left(n_{1}+n_{2}\right)-2$ at a significant level of 5\%. One party hypothesis test results can be seen in Table 6 below.

Table 6. Test of One-Part Hypothesis of Mathematics Learning Outcomes

\begin{tabular}{|c|c|c|c|c|c|}
\hline $\boldsymbol{S}_{\boldsymbol{i}}^{\mathbf{2}}$ & $\boldsymbol{S}_{\boldsymbol{i}}^{\mathbf{2}}$ & Df & $\boldsymbol{t}_{\boldsymbol{c a l}}$ & $\boldsymbol{t}_{\text {tabel }}$ & Conclusion \\
\hline 21,9123 & 73,7933 & 42 & 7,2809 & 1,6803 & $H_{0}$ rejected \\
\hline
\end{tabular}

Based on the results of the analysis carried out with a significance level of 5\% and 42 degrees of freedom, the value of $t_{c a l}=7.2809$ and $t_{\text {table }}=1.6803$, so the value $t_{c a l}>t_{\text {table }}$ then $\mathrm{H}_{0}$ is rejected and $\mathrm{H}_{1}$ is accepted which means that mathematics learning uses more effective mathematics learning CD compared to learning mathematics with learning without using mathematics learning CDs for class VII students in the even semester of MTs Al-Furqon Sanden in the 2015/2016 academic year.

\section{CONCLUSION}

Based on the results of the research and discussion as described above, the research conclusions can be taken as follows:

1. There are differences in mathematics learning outcomes using mathematics learning CDs with learning without using mathematics learning CDs for class VII students of the even semester of MTs Al-Furqon Sanden 2015/2016 academic year. This is indicated by the results of the First hypothesis test with a significant level of $5 \%$ and degrees of freedom $=42$, obtained $t_{c a l}=7.2809$ and $t_{\text {table }}=$ 2.0183, so $t_{c a l}>t_{\text {table }}$ Then reject $\mathrm{H}_{0}$ and $\mathrm{H}_{1}$ accepted.

2. Mathematical learning using mathematics learning CDs is more effective than learning mathematics with learning without using mathematics learning CDs for class VII students in the even semester of MTs Al-Furqon Sanden 2015/2016 academic year. This is indicated by the results of the second hypothesis test wherewith a significant level of $5 \%$ and 42 degrees of freedom, the value of $t_{c a l}=$ 7.2809 and $t_{\text {table }}=1.6803$, so that the value $t_{\text {cal }}>t_{\text {table }}$ then $\mathrm{H}_{0}$ is rejected and $\mathrm{H}_{1}$ is accepted.

\section{REFERENCES}

Daryanto. 2013. Media Pembelajaran (Perananya Sangant Penting Dalam Mencapai Tujuan Pembelajaran). Yogyakarta : Gava Media.

Departemen Pendidikan Nasional. 2008. Panduan Pengembangan Bahan Ajar. Direktorat Pembinaan Sekolah Menengah Atas.

Hamdani. 2011. Strategi Belajar Mengajar. Bandung : Pustaka Setia.

Sudjana, 2001. Metode Statistika edisi 6. Bandung: Tarsito.

Sugiyono, 2011. Metode Penelitian Pendidikan (Pendekatan Kuantitatif, Kualitatif, dan R\&D). Bandung: Alfabeta.

Suparman. 2011. Metodologi Penelitian Pendidikan. Yogyakarta : MIPA Universitas Ahmad Dahlan Press.

2012. Desain dan Analisis Eksperimen. Yogyakarta : Universitas Ahmad Dahlan.

Uno, Hamzah B. 2007. Model Pembelajaran Menciptakan Proses Belajar Mengajar Yang Kreatif dan Efektif. Jakarta: Bumi Aksara. 